\title{
DEBATED ISSUES IN KARAIM HEBREW ORTHOGRAPHY*
}

\author{
ZSUZSANNA OLACH \\ MTA-SZTE Turkological Research Group \\ 6722 Szeged, Egyetem u. 2, Hungary \\ e-mail: zsuzsanna.olach@gmail.com
}

The present study tries to elucidate how the Hebrew alphabet was used in different Karaim manuscripts. Religious and secular texts in all Karaim varieties provide a basis for the comparison. Since a comprehensive description of the relevant orthographic features would exceed the limits of this paper, only two of the most debated characteristics, namely the writing of the $e$ and $k$ sounds, will be discussed here. An analysis of numerous manuscripts makes it possible to provide a general description of certain tendencies and preferences in the use of certain letters or letter combinations in each Karaim variety.

Key words: Halich Karaim manuscripts, Lutsk Karaim manuscripts, Crimean Karaim manuscripts, Trakai Karaim manuscripts, Hebrew script used by the Karaim, the writing of $e$ the sounds, the writing of the $k$ sounds.

\section{Introduction}

The Turkic-speaking Karaim are followers of Karaitism, which is based on Karaite Judaism under the influence of Islam and lately of Christianity (Zajączkowski 1961, pp. 28-29). The main tenet of Karaite Judaism is "Search you through the Torah and do not rely on my opinion", i.e. the Karaites accept only the Torah and reject the post-biblical literature, such as the Talmud (Nemoy 1978, pp. 603-604).

Karaitism arose in the 9th century in the territories of present-day Iraq, but its centre shifted from time to time from the Middle East to the Byzantine Empire in the

* A previous version of this paper was presented at the Szeged Workshop on Karaim Studies held in Szeged (Hungary), 13 June 2014. I would like to thank Professor András Róna-Tas for perusing the paper and for his valuable comments and suggestions. 
13th century and then to Eastern Europe. With the shift of the centre, the language of Karaite scholarly literature changed as well from Arabic to Hebrew. ${ }^{1}$

The scholars and leaders of the Karaim communities were educated in Hebrew and used the Hebrew alphabet for writing both in Hebrew and in their Turkic vernacular. Not only were translations of biblical texts and religious poems written in the Hebrew script, but also private letters (see Németh 2011). Although the Hebrew script remained in use until the 1940s, Karaim started to use the Cyrillic- and the Latinbased alphabets in the 19th century (Csató - Nathan 2007).

\section{Sources Used in the Present Study}

Karaim materials written with the Hebrew alphabet were first published in the 19th century and up to the $1940 \mathrm{~s}$. After a 30 - to 50-year break, new sources - mostly religious texts - have been brought out lately by Turcologists and Hebraists (e.g. Sulimowicz 1972; Jankowski 1997; Csató 2011; Németh 2011; Shapira 2013). These publications have included texts in all varieties and sub-varieties of Karaim, which makes it possible to examine the Hebrew orthography of Karaim to determine whether overall systems or tendencies relevant to certain varieties can be described.

The following Karaim sources were used for the present paper: poems and biblical texts in Halich Karaim (Grzegorzewski 1903, 1917; Jankowski 2011; Olach 2013; 2014; forthcoming), short fragments of Bible translations in Karaim varieties (Kowalski 1929; Zajączkowski 1934), the Trakai Karaim translation of the Book of Proverbs (Firkovičius 2000), the Trakai Karaim translation of Psalm 91 (Csató 2011), Crimean Karaim translations of biblical texts (Sulimowicz 1972; Jankowski 1997), and private letters in Lutsk Karaim (Németh 2011).

In 1903, Jan Grzegorzewski published Halich Karaim religious poems written by Abraham Leonowicz, Josef Mordkowicz and Jakob Josef Leonowicz in the 19th century. Two further poems penned by Josef Ben Jeshua and Josef ben Shemuel in the 17th century were brought out in Język łach-karaitów (Grzegorzewski 1917).

Two prayers for the Day of Atonement written in Halich Karaim were made available by Jankowski (2011) with copies of the manuscripts attached.

Sixty pages of a Halich Karaim family Bible were published by Olach in 2013. The manuscript is in the possession of the Abrahamovich family who originally lived in Halich.

An evening prayer (PR2) and a morning prayer (F103 14-15) written in Halich Karaim were put out by Olach (2014 and forthcoming).

Copies of some fragments of Karaim Bible translations written in the Hebrew script were brought out by Kowalski (1929, pp. 282-289): the beginning of Genesis rendered in 1723 in Deraźnia; different fragments of the Book of Job in different

\footnotetext{
${ }^{1}$ See more about the history of Karaitism in Nemoy (1978).
} 
Karaim varieties; and fragments of Halich Karaim and Crimean Karaim translations of the Song of Songs.

In his comparative study, Zajączkowski (1932; 1934) published short parts of four different Trakai Karaim translations of Lamentations.

The Book of Proverbs in Trakai Karaim was compiled or copied in 1798 in Saločiai (Lithuania) by Shelumiel, the son of the aged priest Shemuel (Firkovičius 2000, pp. 169-170).

In 2011, a Trakai Karaim translation of Psalm 91 was made available by Csató. The manuscript is kept at the Library of the Lithuanian Academy of Sciences.

Prayers in Crimean Karaim translation were edited and published together with a copy of the manuscripts by Sulimowicz (1972).

Jankowski (1997) brought out the Crimean Karaim translation of Genesis 1:118; 6:9-18; 17:8-19; Deuteronomy 32:1-51; and Lamentations 4:11-15, 21. The manuscript for these biblical texts is kept in the Rylands Library collection in Manchester. Although no copy of the manuscript is attached to the article, Jankowski used a transliteration system that makes it possible to reconstruct the Hebrew orthography.

Németh (2011) published 16 letters and circulars written in Lutsk Karaim. Most of the texts were written in the 19th century, but three of them were penned in the early 20th. Six of the letters are vocalised, whereas four of the texts are only partly vocalised.

It is transparent from the list of materials used in this study that the corpus contains texts reflecting a spoken variety (the Lutsk Karaim private letters) as well as religious texts written by Karaim authors and translations of biblical texts. It must be emphasised that spoken Karaim differs significantly from the written language. Since creating and/or copying Bible translations has enjoyed a long tradition among the Karaim, the orthography of the biblical texts is more consistent and systematic. The Lutsk Karaim private letters, however, due to the subjective use of the Hebrew alphabet for writing in Karaim, show a variety of orthographic features (Németh 2011, pp. 100-101). Yet basic notions about the use of the Hebrew script seem common in Karaim communities, and the different varieties and genres demonstrate shared characteristics.

In the following, two debated characteristics of Karaim Hebrew orthography, namely the writing of the $e$ and $k$ sounds, will be discussed in detail; further research is required to describe other characteristics.

\section{Notation of the $e$ Sounds}

The writing of the $e$ sounds shows great diversity in Karaim. Furthermore, we must distinguish the notation in vocalised and non-vocalised texts. In what follows, I discuss the forms of writing of the vowel $e$ according to its occurrence in vocalised and non-vocalised texts.

In the literature, two types of $e$ sounds (an open $\ddot{a}$ and a closed $e$ ) are distinguished in the Lutsk-Halich Karaim varieties. According to earlier studies, the occur- 
rence of the closed $e$-due to the process of $q \ddot{i}>k^{\prime} e$ - results from the influence of the surrounding Ukrainian varieties (Grzegorzewski 1917, pp. 7-8; Pritsak 1959, p. 327; Dubiński 1978, p. 36). ${ }^{2}$ On the other hand, Dubiński (1978, p. 36) describes another process in Lutsk-Halich Karaim: $\ddot{a}>e$ before a syllable with the vowel $i$. Németh (2011, p. 73) suggests Western Ukrainian influence in this latter process as well.

The open $\ddot{a}$ and the closed $e$ are also distinguished in Crimean Karaim (Sulimowicz 1972, p. 42; Jankowski 1997, pp. 4-5). The closed $e$, however, occurs only in the first syllable (Jankowski 1997, p. 8).

Descriptions of the $e$ sounds occurring in Trakai Karaim - sometimes introducing the idea of consonant harmony (see Kowalski 1929, pp. XXX-XXXI; Pritsak 1959, p. 328) - are often rather obscure (Kowalski 1929, pp. XXVIII-XXIX; Musaev 1964, pp. 46-47). Different qualities of $e$ sounds which are distinguished even in the present Lithuanian-based orthography (see Firkovičius 1996), however, can be described: [e], [ع] and [æ] (Csató 2012, p. 36).

Now let us turn to the use of the different letters and letter combinations for writing the $e$ sounds.

\section{In Non-vocalised Texts}

The notation of the vowel e/ $\ddot{a}$ often overlaps with the writing of the vowel $i / \ddot{i}$ in Karaim non-vocalised texts: ${ }^{3}$ both are written with the letter 'ále $\bar{p}+y \bar{o} \underline{d}$ in initial position, e.g. 11: 20 ezi 'himself' (איזי) (אישי) (אינג) vs. 11: 15 isteme 'to ask, want' (אישטימי) and 54': 38 icin 'for' (איצין) (Németh 2011, pp. 385, 398). ${ }^{4}$ The initial $e$ sounds, however, can only be signified with an ále $\bar{p}$, i.e. without $y \bar{o} \underline{d}$ as well, e.g. 8: 7 ekinci 'secondly' (אכינצי), ${ }^{5} 46^{11}: 15$ elimi 'his death' (אלימי) (Németh 2011, pp. 382, 387). ${ }^{6}$

Medial $e$ is mostly rendered by $y \bar{o} \underline{d}$; in numerous cases, however, it may not be indicated at all, e.g. 8: 7 bitiklerine 'to your letters' (ביטיקליריני) and 10: 5 kelme 'to come' (כילמי) vs. 10: 16 izlewci 'the one who seeks' (איזלווצי) and 46 11 men 'I'

\footnotetext{
${ }^{2}$ It seems that the $q \ddot{i}>k^{\prime} e$ process is less productive in Lutsk Karaim, which is understandable since it is not recorded in the Ukrainian varieties in the region of Lutsk (Németh 2011, p. 74).

${ }^{3}$ In another consonantal alphabet of Semitic origin used for writing Turkic, that is, in Arabic script the same letter $(y \bar{a})$ is used both for the notation of /e/ and /i/ (Róna-Tas 1998, p. 131).

${ }^{4}$ In the quoted examples, my own transcription system is employed. I use the following vowel signs in my transcription: $a, e, \ddot{a}, i, \ddot{i}, o$ and $u$. The following consonants occur: b, c, č, d, f, g, g, h, $\chi, \mathrm{y}, \mathrm{k}, \mathrm{q}, 1, \mathrm{~m}, \mathrm{n}, \mathrm{p}, \mathrm{r}, \mathrm{s}, \mathrm{s}, \mathrm{t}, \mathrm{w}, \mathrm{z}$ and '. The letter ś represents the Hebrew letter śîn/šîn. In my transcription, I do not mark palatalisation. The original transcription of an example is given in square brackets only when it is relevant for the discussion.

${ }^{5}$ The word ekinci is written with 'álep $+y \bar{o} \underline{d}$ in initial position a few lines later in the same text: 8: 14 ekinci 'secondly' (איכינצי) (Németh 2011, p. 382).

${ }^{6}$ Németh writes the word as אילימי note 305 in Németh $(2011$, p. 185). In the facsimile, however, I do not see a $y \bar{o} \underline{d}$ written between the 'álep and the lámed (Németh 2011, p. 387).
} 
(מן) (Németh 2011, pp. 382, 384, 387). Yet this is not the case in suffixes, e.g. $54^{11}: 21$ klemedler 'they did not want' (כלימידליר) (Németh 2011, p. 398). For final $e$, we find $y \bar{o} \underline{d}$ or, slightly less frequently, yō $\underline{d}$ and 'ále $\bar{p}$, e.g. 11: 12 haliginede 'in these times' (הליגינידי), $54^{11}: 18$ ne 'which' (ני), and 10: 5 biyencine 'to her wedding' (ביינציניא) (Németh 2011, pp. 384, 385, 397).

According to Jankowski (1997, p. 5), like the vowel $a$, the vowel $e / \ddot{a}$ is usually not marked in medial position in the Crimean Karaim Bible translations.

\section{In Vocalised Texts}

The notation of the vowel $\ddot{a}$ is only indicated in the Trakai Karaim and Crimean Karaim sources. In Trakai Karaim, the combination pátah $+y \bar{o} \underline{\underline{d}}$ is used to signify the vowel ä, e.g. kečänin 'of the night' (כיצַיאנִין) from Psalm 91 (Csató 2011, p. 15), telilär 'fools' (טֵיליריר) from Proverbs 1 (Firkovičius 2000, p. 97), and keräkli 'neces-

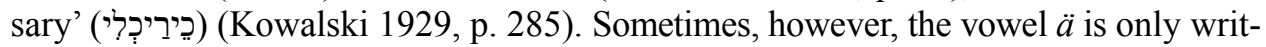
ten with the letter pátah, e.g. in final position in the word haleginä 'now' (הלְגינַ) and in the third syllable in kičiräklär 'smaller ones' (כִיצִיבכְלִיר) (Kowalski 1929, p. 285).

The letter pátah indicating open $\ddot{a}$ is general in Crimean Karaim, e.g. kečä

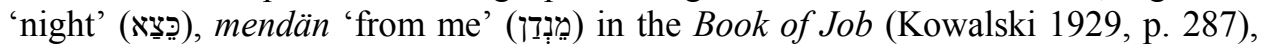

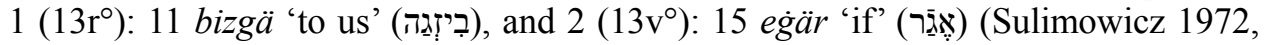
pp. 65-66).

Further Hebrew letters and letter combinations are used to write the vowel $e$ : $s \bar{e} r \hat{e}, s \partial \bar{g} \bar{o} l, s \underline{e} r \hat{e}+y \bar{o} \underline{d}$ and $s \partial \bar{g} \bar{o} l+y \bar{o} \underline{d}$. A general overview of how the vowel $e$ is written in Karaim manuscripts can be seen in Table 1 (see p. 188); that is, all the letters and letter combinations which have occurred in the manuscripts published so far are given here.

Now let us see whether all these forms of writing indicate any phonetic differences or not and whether there is any tendency within a certain Karaim variety?

Most of the forms mentioned above (șerê, saḡo $l, s \bar{e} r \hat{e}+y \bar{o} \underline{d}$ and $s \partial \bar{g} \bar{o} l+y \bar{o} \underline{d}$ ) can be attested in the Halich Karaim sources. Variants with the letter $y \bar{o} \underline{d}$ are used in initial position, e.g. Nr. II: 8 erkim 'my strength' (אֶירְִִים) (Grzegorzewski 1903, p.

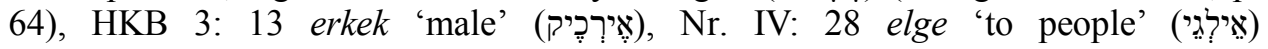

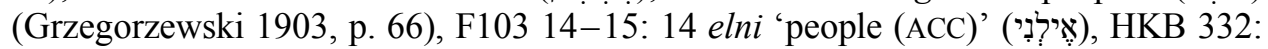
6 erenler 'men' (אירְירְלֶיר), and F103 14-15: 16 ez 'self' (איז), while șèrê and saḡōl

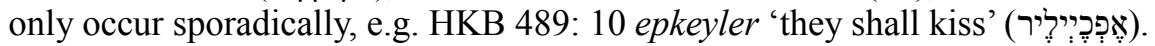

In final position, only variants with $y \bar{o} \underline{d}$ are used, usually followed by the letter

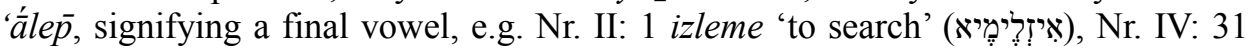
tirligine 'to his life' (טירְלִיגיניניא) (Grzegorzewski 1903, pp. 64, 66), HKB 332: 12 śebe-

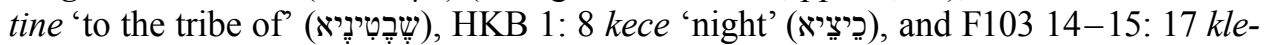

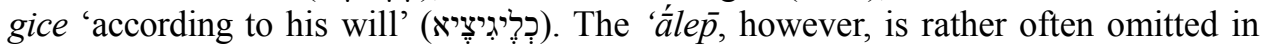

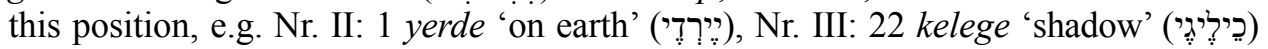
(Grzegorzewski 1903, pp. 64, 65). KUK: 1 kinde 'on the day' (כִירְינִדי), KUK: 8 bizge 'to 
Table 1. Hebrew letters and letter combinations for writing $e$ sounds

\begin{tabular}{|c|c|c|c|c|c|}
\hline $\begin{array}{c}\text { Hebrew } \\
\text { orthography }\end{array}$ & $\begin{array}{c}\text { Value of the vowel } \\
\text { in Hebrew }\end{array}$ & $\begin{array}{l}\text { Crimean } \\
\text { Karaim }\end{array}$ & $\begin{array}{l}\text { Trakai } \\
\text { Karaim }\end{array}$ & $\begin{array}{l}\text { Halich } \\
\text { Karaim }\end{array}$ & $\begin{array}{c}\text { Lutsk } \\
\text { Karaim }\end{array}$ \\
\hline pátah _ & short a & $\mathrm{a}, \mathrm{a}$ & $\mathrm{a}, \mathrm{ä}$ & $\mathrm{a}$ & $\mathrm{a}$ \\
\hline$s a \bar{g} \bar{o} l$. & short e (open) & - & $\mathrm{e}$ & e & $\mathrm{e}$ \\
\hline șērê.. & $\begin{array}{l}\text { changeable long e } \\
\text { (closed) }\end{array}$ & $\mathrm{e}$ & $\mathrm{e}$ & $\mathrm{e}$ & $\mathrm{e}$ \\
\hline \multicolumn{6}{|c|}{ Combinations with $y \bar{o} \underline{d}$, } \\
\hline pátah + yō $\underline{d}$,- & - & - & $\ddot{a}$ & - & - \\
\hline$s \partial \bar{g} \bar{o} l+y \bar{o} \underline{d}$ & $\begin{array}{l}\text { unchangeable long e } \\
\text { (open) }\end{array}$ & - & $\mathrm{e}$ & $\mathrm{e}$ & $\mathrm{e}$ \\
\hline$s \bar{e} r \hat{e}+y \bar{o} \underline{d}$ & $\begin{array}{l}\text { unchangeable long e } \\
\text { (closed) }\end{array}$ & - & $\mathrm{e}$ & $\mathrm{e}$ & $\mathrm{e}$ \\
\hline
\end{tabular}

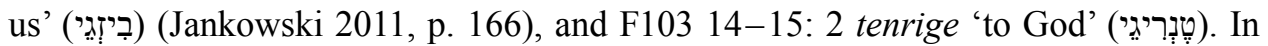
rare cases, the final $e$ is written without $y \bar{o} \underline{\underline{d}}$ (and followed by 'álep): PR2: 8 tirlikke

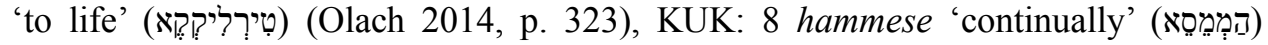

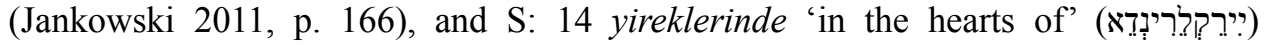
(Jankowski 2011, p. 167).

In medial position, all graphic variants occur in the Halich Karaim sources, but the proportion of variants with $y \bar{o} \underline{d}$ is significantly higher than that of variants

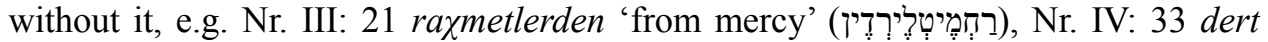
'four' (דָרִּר) (Grzegorzewski 1903, pp. 65, 66), HKB 1:1 keklerni 'skies (ACC)'

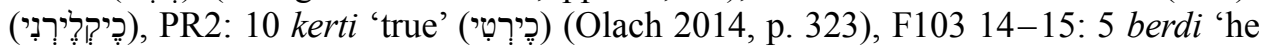

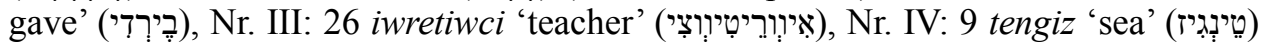
(Grzegorzewski 1903, pp. 65, 66), HKB 7: 27 nege 'why?' (ניגֶֶיא), and F103 14-15: 23 hec 'empty' (היץ).

The use of allographs without $y \bar{o} \underline{d}$ shows certain regularities: they are preferred in certain lexical items, e.g. tenri 'God' (טְנְִרי), and in the personal pronouns 'I' and 'you' as well as in the personal suffixes for the first and second person singular, i.e. men and sen. In general, the letter sağ $\bar{o} l$ is used in these cases, e.g. Nr. II: 15 sen 'you' (סָ), Nr. III: 21 tolusen 'you are full' (טוֹלוְְּן) (Grzegorzewski 1903, pp. 64, 65),

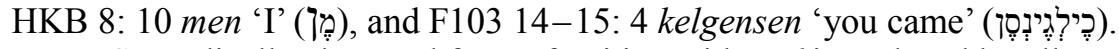

Sporadically, the usual form of writing with $y \bar{o} \underline{d}$ is replaced by allographs without $y \bar{o} \underline{d}$. For instance, the regular way of writing the palatal form of the locative and

${ }^{7}$ The value of Hebrew vowels can change according to stress patterns; see, for instance, the rules of vowel reduction (Lambdin 1971, pp. XIX-XX). For more, see the chapter on Sound and Spelling in Lambdin (1971, pp. XV-XXVIII). 


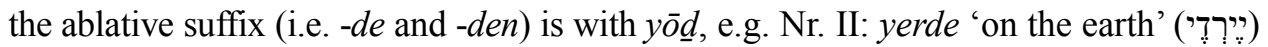

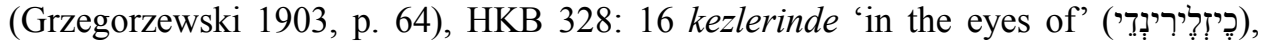

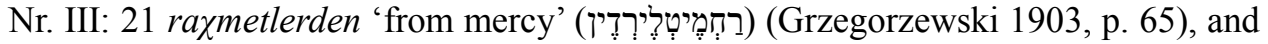

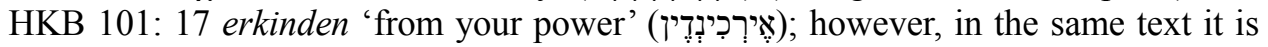
sometimes written with the letter saḡol: HKB 487: 18 iwlerinde 'in their houses'

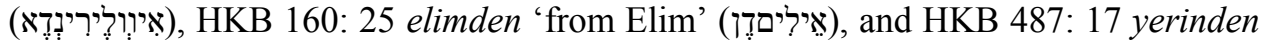

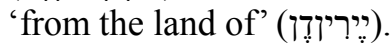

Examples with more than one form of writing can also be attested: Nr. II: 16 kerers 'you will see' (כָירְירְס) vs. Nr. II: 17 ker! 'see (IMP)' (כֶיר) (Grzegorzewski

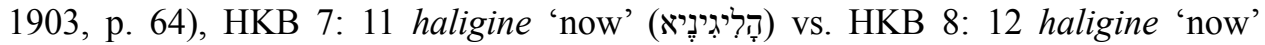

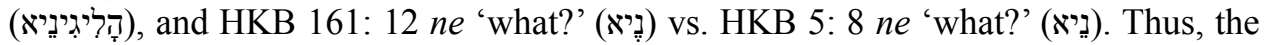
distinction between $s \partial \bar{g} \bar{o} l$ and șêrê seems to be a free graphic variation in Halich Karaim.

The use of the letter șerê is rather limited in the Halich Karaim sources, e.g. Nr. II: 21 ye 'udlarnï 'Jews (ACC)' (כייעוּדָדְרִיר) (Grzegorzewski 1903, p. 64), T2: 71 keśkin! 'cut off (IMP)' (כָשְככין) (Grzegorzewski 1917, p. 23), and HKB 489: 9 ceyalïgï

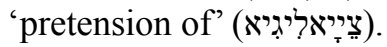

In the Lutsk Karaim sources, in contrast with the Halich Karaim materials, the letter șêrê and its combination with $y \bar{o} \underline{d}$ are widely used and the letter $s \partial \bar{g} \bar{o} l$ and its combination with $y \bar{o} \underline{d}$ rarely occur (Németh 2011, p. 108).

Initial $e$ is usually represented as șerê $+y \bar{o} \underline{d}$, preceded by an 'ále $\bar{p}$ to indicate the initial vowel, e.g. 6 (81): 6 ekinci 'second' (אֵיכִינְצִי) (Németh 2011, pp. 378, 386). In rare cases, the Hebrew letter is used without $y \bar{o} \underline{d}$; that is, only the letter șêrê occurs, e.g. 9/2: 8 ezimiz 'ourselves' (אָזr) (Németh 2011, p. 383).

In medial position, the vowel $e$ is usually signified by șerê $+y \bar{o} \underline{d}$, e.g. 3 (78):

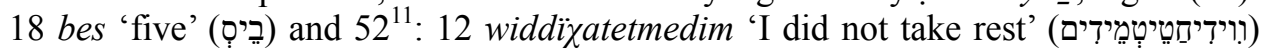
(Németh 2011, pp. 375, 394), or, a little less frequently, only with șêrê, specially in the environment of the consonant $y$, e.g. 7 (82): 30 iyer 'he will send' (אי...) and 52 17 meni 'me (ACC)' (מֵני) (Németh 2011, pp. 380, 394). Final $e$ is generally written with

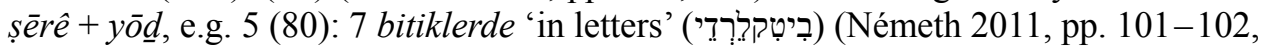
377). The letter 'álep̄ representing the final vowel can also occur after the letter com-

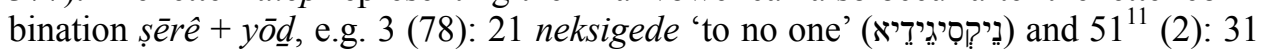
kere 'according to' (כָיריא) (Németh 2011, pp. 375, 392).

The letter $s a \bar{g} \bar{o} l$ rarely occurs in the Lutsk Karaim manuscripts. In initial posi-

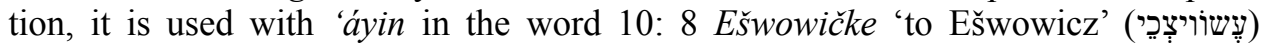
(Németh 2011, p. 384). Sometimes $s \partial \bar{g} \bar{l} l$ can be attested in medial position, e.g. 7 (82):

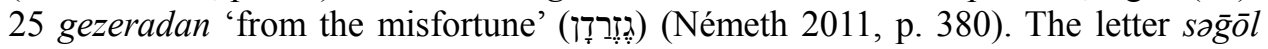
does not occur in final position. As for the letter combination $s \partial \bar{g} \bar{o} l+y \bar{o} \underline{d}$, it can only

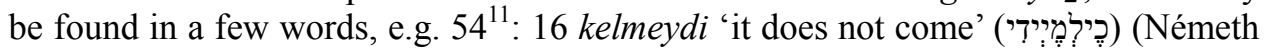
2011, p. 108).

As for the question of difference in quality indicated by the use of different letters, numerous examples seem to disprove such a hypothesis. In the Halich and Lutsk Karaim varieties, we would expect closed $e$ in the first syllable and open $\ddot{a}$ in subse- 
quent syllables. Although there are certain preferences in each variety, as the examples show, both șerê and saḡol as well as their combinations with $y \bar{o} \underline{d}$ are used in the first syllable in the Halich Karaim and Lutsk Karaim sources. Similarly, all the Hebrew letters and letter combinations for writing the $e$ sounds occur in the second syllable or any syllable thereafter; however, the use of $s \partial \bar{g} \bar{o} l$ and $s \partial \bar{g} \bar{o} l+y \bar{o} \underline{d}$ is rather restricted in Lutsk Karaim, and no letters without $y \bar{o} \underline{d}$ can be found in final position in the Halich Karaim texts. Thus, we cannot classify the Hebrew letters and letter combinations as being representative of certain vowel qualities. Words in several forms of writing might confirm this assertion as well.

The Crimean Karaim authors only use the letters șerê and saḡōl; letters combined with $y \bar{o} \underline{d}$ do not occur. Both șêrê and saḡōl are employed in initial and medial

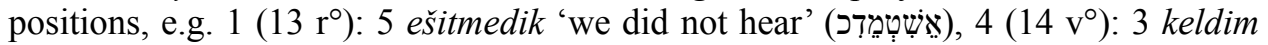

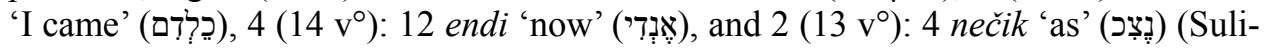
mowicz 1972, pp. 65, 66, 68). There are words in which the two letters seem to be

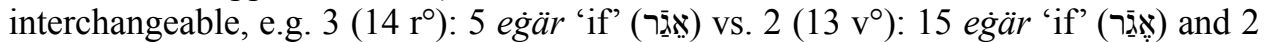

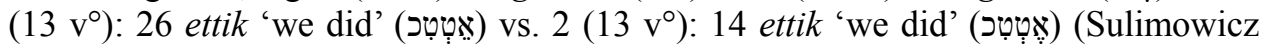
1972 , p. 66). In final position, only the open $\ddot{a}$ is used (see above). Since a clear distinction exists between the writing of open $\ddot{a}$ and closed $e$ in the Crimean Karaim orthography, the use of the letter șērê or $s \partial \bar{g} \bar{o} l$ in different positions seems to be equivalent.

In Trakai Karaim, we mostly see the use of the letter combination șerrê $+y \bar{o} \underline{d}$ or the letter șêrê (often in the environment of the consonant y), e.g. seni 'you (ACC)'

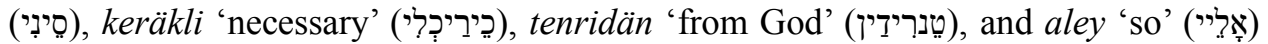
(Kowalski 1929, pp. 285, 288; Firkovičius 2000, pp. 107, 110). The letter combination șerê $+y \bar{o} \underline{d}$ usually occurs in initial position, e.g. edi 'was' (אידי) and eger 'if' (Wיגיגיר) (Zajączkowski 1932, p. 184; Firkovičius 2000, p. 98). In rare cases, however, the letter șêrê is used in initial position, e.g. ( $\chi o r)$ etkäydim 'I would have disdained'

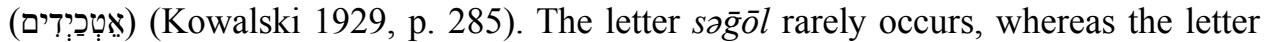
combination $s \partial \bar{g} \bar{o} l+y \bar{o} \underline{d}$ is the least used form for writing the vowel e, e.g. yergä 'to

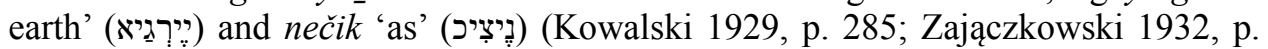
184). The latter two occur only in medial position. It is mostly open $\ddot{a}$ written with pátah $+y \bar{o} \underline{d}$ or pátah that can be found in final position (see above), but, in some exceptions, the letter combination șerrê $+y \bar{o} \underline{d}$ (sometimes followed by 'ále $\bar{p}$ ) is used, e.g. vale 'but' (וַולי) and kelse 'if he comes' (כילְסיא) (Firkovičius 2000, pp. 103, 116). As the examples demonstrate, the distinction indicated in the present Trakai Karaim orthography does not correspond to the distribution of the Hebrew letters and letter combinations used in the manuscripts.

To sum up, the following tendencies can be observed in the Karaim sources for writing the $e$ sounds. Halich Karaim writers prefer to use letter combinations with $y \bar{o} \underline{d}$. In Lutsk Karaim and Trakai Karaim, it is mostly the letter combination șerrê +

\footnotetext{
${ }^{8}$ Note that Firkovičius $(2000$, pp. 5,14$)$ transcribes the word kelse 'if he comes' as [kiel'sia], that is, șêrê $+y \bar{o} \underline{d}$ followed by 'ále $\bar{p}$ denotes $\ddot{a}$ in this case, whereas the same letter combination is used for writing $e$ in the word vale [valie] 'but'.
} 
$y \bar{o} \underline{d}$ or the letter șerê that is used, whereas no letter combinations with $y \bar{o} \underline{d}$ can be attested in the Crimean Karaim texts. See the details in the following table, where the sign +++ denotes the most often used form, ++ marks the rather usual form and the least used sporadically occurring letters and letter combinations are indicated with + .

Table 2. Tendencies for writing the $e$ sounds

\begin{tabular}{|c|c|c|c|c|c|}
\hline Preferences & & $\begin{array}{l}\text { Crimean } \\
\text { Karaim }\end{array}$ & $\begin{array}{c}\text { Trakai } \\
\text { Karaim }\end{array}$ & $\begin{array}{c}\text { Halich } \\
\text { Karaim }\end{array}$ & $\begin{array}{c}\text { Lutsk } \\
\text { Karaim }\end{array}$ \\
\hline & pátah & +++ & + & - & - \\
\hline & pátah $+y \bar{o} \underline{d}$ & - & +++ & - & - \\
\hline \multirow{2}{*}{ Letters without $y \bar{o} \underline{d}$} & șerê & +++ & +++ & ++ & ++ \\
\hline & $s \partial \bar{g} \bar{o} l$ & +++ & + & ++ & + \\
\hline \multirow{2}{*}{ Letters with $y \bar{o} \underline{d}$} & $s \underline{e} r \hat{e}+y \bar{o} \underline{d}$ & - & +++ & +++ & +++ \\
\hline & $s \partial \bar{g} \bar{o} l+y \bar{o} \underline{d}$ & - & + & +++ & + \\
\hline
\end{tabular}

Although the way in which the Hebrew letters and letter combinations are used does not always reflect the linguistic descriptions of Karaim varieties, certain tendencies can be observed. With regard to the writing of the vowel $e$ in the Karaim manuscripts that use the Hebrew alphabet, the Crimean Karaim (i.e. the Eastern Karaim) orthography preferring letters without $y \bar{o} \underline{d}$ is distinct from the orthographic features of the other Karaim varieties (i.e. of the Western Karaim). Meanwhile, a tendency can be observed among the Western Karaim varieties in the use of either șerê $+y \bar{o} \underline{d}$ or simply șêrê.

\section{The Use of the Letters $k a \bar{p}$ and $q \bar{q} p$}

Two letters are used to write the consonant $k$ in Hebrew: $k a \bar{p} \supset$ and $q \bar{o} p$ p. In Biblical Hebrew, the phonetic value of $k a \bar{p}$ is front $k$, while that of $q \bar{o} p$ is back $q$ (Lambdin 1971 , p. XXIII). In the Karaim sources, both letters are used to indicate the $k$ sounds. Is it the case that the phonetic values represented by kap and $q \bar{o} p$ in Hebrew are also represented as such in the Karaim manuscripts? Or are they used for signifying some other phonetic differences?

The question of the $k$ sounds is not well described in the early literature on the Karaim varieties. It is usually the palatalising effect of $k i$ and $k^{\prime} e$ on the preceding consonant which is noted (Grzegorzewski 1917, p. 6; Kowalski 1929, p. XLI; Zajączkowski 1931, p. 8). In the table of Karaim consonants, Pritsak only lists $q, k^{\prime}$ and $y$ as elements of the Halich Karaim consonant inventory. However, according to him, the 
following $k$ sounds can be found in initial position: $q$ - and $k$-. ${ }^{9}$ Pritsak (1959, p. 328) observes that consonants become palatalised before the vowel $i$ and that the palatalised consonants $\dot{c}, \dot{s}, \dot{z}$ and $\dot{n}$ occur before certain syllables, among them $k^{\prime} i$ and $k^{\prime} \ddot{a}$. The vowel $\ddot{a}$ has basically no palatalising influence on surrounding consonants, except on the preceding $k$ (Pritsak 1959, p. 327). According to Dubiński (1978, pp. 38-39), consonants in Halich Karaim undergo palatalisation in the environment of palatal vowels but the consonant $k$ becomes palatalised only before the vowel $e$, e.g. $k$ 'erme 'to see' and iśk' ${ }^{\prime}$ 'to work'. ${ }^{10}$

As for a description of the notation of the $k$ sounds in the Karaim manuscripts written with the Hebrew alphabet, there is a common point in the literature: $k a \bar{p}$ is basically used to write the $k$ sounds in front words and $q \bar{o} p$ to represent $k$ in back words (Munkácsi 1909, p. 192; Pritsak 1959, p. 327; Németh 2011, pp. 103-104). The occurrence of $q \bar{o} p$ in front words, however, is described and explained in different ways. Munkácsi (1909, p. 192) states that the letter $q \bar{o} p$ can occur between a palatal vowel and a consonant, i.e. in word-internal position. Pritsak (1959, p. 327) observes that $k$ can be written with $q \bar{o} p$ in the syllable-final position. According to Sulimowicz (1972, p. 45), in Halich Karaim, $k a \bar{p}$ and $q \bar{o} p$ were used interchangeably and no rules defined their usage. Németh (2011, pp. 103-104) has proposed that the two letters in Lutsk Karaim tend to render the palatalised and the non-palatalised $k$ sounds; that is, $k a \bar{p}$ is used for palatalised $k$ and $q \bar{o} p$ represents non-palatalised $k$.

In the Halich Karaim manuscripts, the letter $k a \bar{p}$ is generally used - mostly in initial and medial positions - to signify the consonant $k$ in front words, e.g. in Nr. II: 19 kle! 'want (IMP)' (כְלְיא) (Grzegorzewski 1903, p. 64), T1: 13 keldim 'I came' (כְלְדְים)

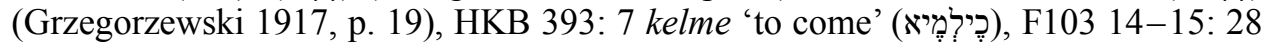

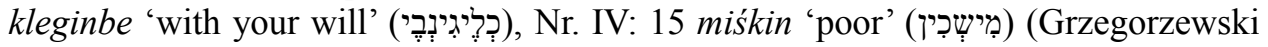

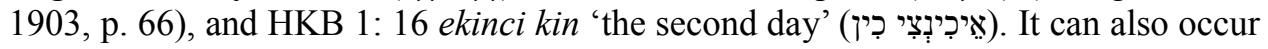
in back environments in loanwords, such as KUK: 1 kohen 'priest' (פָהן) (Jankowski 2011, p. 166).

The letter $q \bar{o} p$ is used in back words in all positions, e.g. Nr. III: 8 qoyun 'lamb'

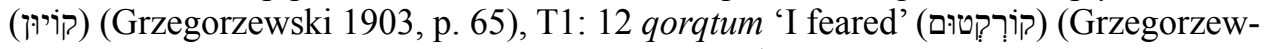
ski 1917, p. 19), HKB 1: 3 qarangilliq 'darkness' (סרנְגִיליק), HKB 397: 14 cuqcumagïn

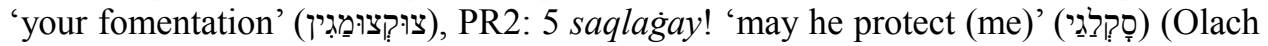
2014, p. 323), and F103 14-15: 21 qabulluq 'acceptance' (קבוּלְוּוּק). It appears, however, even in palatal words, mostly in syllable- or word-final positions, e.g. T1: 52 kekten 'from the sky' (כֶיקטֶׁ) (Grzegorzewski 1917, p. 20), S: 20 eśiklerimni 'my

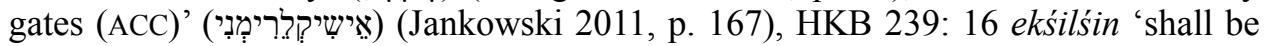

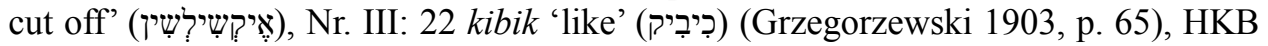

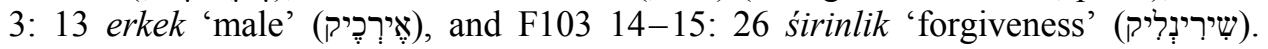
In rare cases, the letter $q \bar{o} p$ occurs in initial position in front words, e.g. HKB 155: 3

\footnotetext{
${ }^{9}$ In the list of Halich Karaim consonants, there is no consonant $k$, and $k^{\prime}$ is not mentioned in initial position; however, the examples provided by Pritsak (1959, pp. 327-329) include $k^{\prime} a ̈ t-$ gäntär 'those who came'.

${ }^{10}$ Consider Dubiński's (1978, pp. 38-39) examples with the consonant $k$ before the vowel $i$ : ićki 'drink', kicli 'strong' and miśkin 'poor'.
} 
kezlerin 'your eyes' (קיזְלְירירין) and PR2: 6 kiri (tutqay!) 'may he keep (me) alive' (קירין) (Olach 2014, p. 323).

In the Lutsk Karaim sources, there is also a tendency attested in the use of kap and $q \bar{o} p$. Similarly to the Halich Karaim materials, the letter kap̄ is used in front words and the letter $q \bar{o} p$ in back words, e.g. 41: 5 keldi 'it came' (כירְי?י), $47^{11}$ : 14 ekinci 'second' (איכינצ), and 46 13 terk 'quick, quickly' (טירכ), on the one hand, and 10:4 qolamen 'I ask' (קולא מן), 6 (81): 12 basqa 'other' (בָשָקָא), and 9: 13 bas yapmaq 'to cover (the bride's) head' (בס ייפמק), on the other (Németh 2011, pp. 378, 383-384, 386-388).

The letter $k a \bar{p}$, however, is also used in a few back words of foreign origin, e.g. 5 (80): 6 kabul 'acceptance' (כַבְּר), 10: 16 kanuzga 'to sire' (כנוזגא), and $51^{11}: 5$

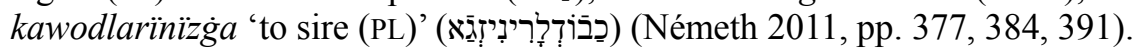

Nevertheless, the letter $q \bar{o} p$ often occurs in medial and final positions in front

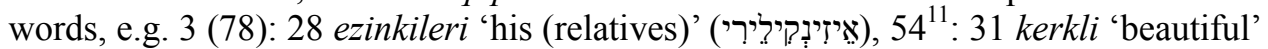
(כירקלי), 2 (77): 25 terk 'quick' (טירקי), 2 (7), 25 kerek 'necessary' (80): 8 bitik 'letter' (ביטיטיק), 7 (82): 16 necik 'as' (ניריקיק), and 7 (82): 22 yiśraellik 'Karaims' (ישראלליק) (Németh 2011, pp. 372, 376-377, 380, 398). Furthermore, the letter qōp is used rather often in initial position in front words, e.g. 3 (78): 11 kezlerinizde 'in your

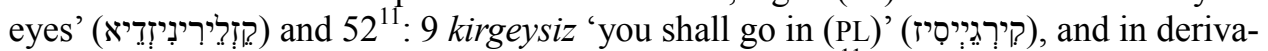
tives of the verbal stem kle- 'to want, wish', e.g. 47': 32 klep 'wishing' (קלריף) (Németh 2011, pp. 375, 389, 394).

There are items which are sometimes written with the letter $k a \bar{p}$ and other times with the letter $q \bar{o} p$. The word kerkli 'beautiful', for instance, occurs five times in the Lutsk Karaim texts: four times with $k a \bar{p}$ in medial position and once with $q \bar{o} p$. Derivatives of kle- 'to want, wish' appear seventeen times: twelve times written with kap and five times with qōp. Further examples are 10:7 laskawïy 'generous' (לאסקאוויי) vs. 8: 9 laskawiy 'generous' (לסכאביי), 2 (77): 3 necik 'as' (ניציק) vs. 46: 13 necik 'as' (ניציכ), and 54 38 kin 'day' (כין) vs. 6 (81): 6 kin 'day' (כין) (Németh 2011, pp. 372, 382, 384, 387).

Németh (2011, pp. 103-104) suggests that the reason behind the use of $q \bar{o} p$ in front words is the phonetic rule that it is always $k$ that is signified by $q \bar{o} p$ in wordfinal position, not palatalised $k^{\prime}$. Exceptions, on the other hand, can also be attested, e.g. 3 (78): 28 ezinkileri [eźińkiłeri] 'the relatives of' (אייזְינְקילִירירי).

The consonant $k$ is always written with the letter $k a \bar{p}$ in front words in Trakai

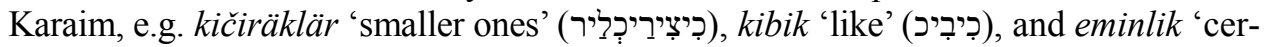
tainty’ (אינמִינְליכ) (Kowalski 1929, p. 285; Firkovičius 2000, p. 100). In initial position in back words, back $q$ is preserved in Trakai Karaim, while it changes to $\chi$ in syllableand stem-final positions (Pritsak 1959, p. 329). The phonetic difference, however, is

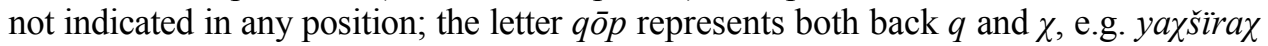

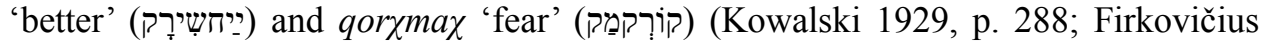
2000, p. 97). Thus, this characteristic in Halich and Lutsk Karaim orthography cannot be observed in Trakai Karaim. The only exception occurs in a translation which was in the possession of Zacharja Mickiewicz in 1929: ešeklär 'donkeys' (אָשׁקָליר) (Kowalski 1929, p. 282). 
In general, front $k$ is written with the letter $k a \bar{p}$ in Crimean Karaim, and back $q$

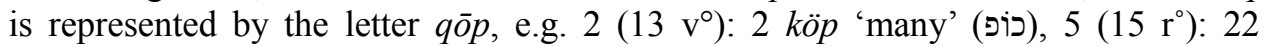

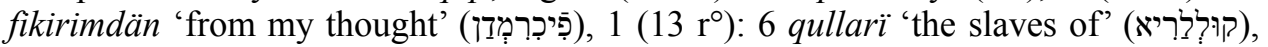

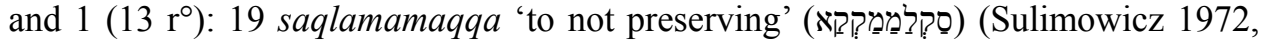
pp. $65,66,69)$. The distinction is also made in syllable- and stem-final positions; that is, front $k$ is written with $k a \bar{p}$ and back $q$ with $q \bar{o} p$, e.g. $2\left(13 \mathrm{v}^{\circ}\right)$ : 12 kökgä 'to

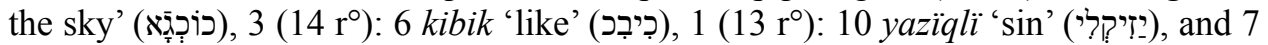

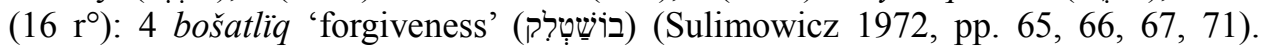
Thus, syllable- or stem-final front $k$ is never written with the letter $q \bar{o} p$ in Crimean Karaim. In loanwords, however, the letter kap may occur in back words as well, e.g.

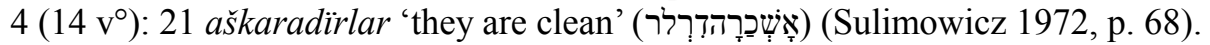

Although the usual way of writing spirant $\chi$ in Crimean Karaim is with the

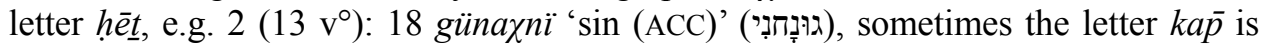
used in conjunction with the diacritical mark rāpeseh, e.g. $3\left(14 \mathrm{r}^{\circ}\right)$ : 8 yaxšilïq 'goodness' (יַכְשִירְי) (Sulimowicz 1972, p. 67).

In summary, the Hebrew letters kap and $q \bar{o} p$, based on the frontness and backness of a particular word, are used rather consistently in Trakai Karaim and Crimean Karaim. In Halich Karaim and Lutsk Karaim, on the other hand, besides the typical distribution of the Hebrew letters, $q \bar{o} p$ also occurs in front words and $k a \bar{p}$ in back words. Table 3 illustrates the occurrences in the Halich Karaim and Lutsk Karaim manuscripts.

\section{Table 3. The use of the letters $k a \bar{p}$ and $q \bar{o} p$ in the Halich Karaim and Lutsk Karaim sources}

\begin{tabular}{|c|c|c|c|c|c|c|c|c|}
\hline & \multicolumn{4}{|c|}{ In front words } & \multicolumn{4}{|c|}{ In back words } \\
\hline & \multicolumn{2}{|c|}{ The letter $k a \bar{p}$} & \multicolumn{2}{|c|}{ The letter $q \bar{o} p$} & \multicolumn{2}{|c|}{ The letter $k a \bar{p}$} & \multicolumn{2}{|c|}{ The letter $q \bar{o} p$} \\
\hline & $\begin{array}{l}\text { Halich } \\
\text { Karaim }\end{array}$ & $\begin{array}{c}\text { Lutsk } \\
\text { Karaim }\end{array}$ & $\begin{array}{l}\text { Halich } \\
\text { Karaim }\end{array}$ & $\begin{array}{c}\text { Lutsk } \\
\text { Karaim }\end{array}$ & $\begin{array}{l}\text { Halich } \\
\text { Karaim }\end{array}$ & $\begin{array}{c}\text { Lutsk } \\
\text { Karaim }\end{array}$ & $\begin{array}{l}\text { Halich } \\
\text { Karaim }\end{array}$ & $\begin{array}{c}\text { Lutsk } \\
\text { Karaim }\end{array}$ \\
\hline Initial & +++ & +++ & + & +++ & + & ++ & +++ & +++ \\
\hline Medial & +++ & +++ & +++ & +++ & + & ++ & +++ & +++ \\
\hline Final & - & + & +++ & +++ & - & + & +++ & +++ \\
\hline
\end{tabular}

Given the results of my research, I cannot agree with Sulimowicz's statement about the interchangeability of the letters $k a \bar{p}$ and $q \bar{o} p$ in the Halich Karaim and Lutsk Karaim manuscripts. Numerous examples seem to contradict Németh's assumption that $k a \bar{p}$ signifies palatalised $k^{\prime}$ and that $q \bar{o} p$ is used for non-palatalised $k$, for instance, the occurrence of $q \bar{o} p$ in initial and medial positions in front words which are transcribed with a palatal $k^{\prime}$ by Németh (2011, pp. 375, 376, 377, 394): 3 (78): 11 kezlerinizde

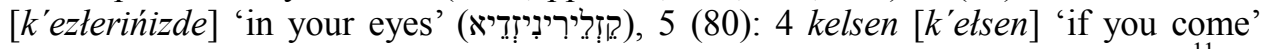

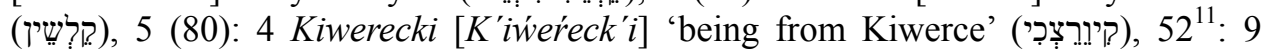




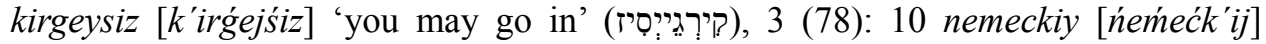

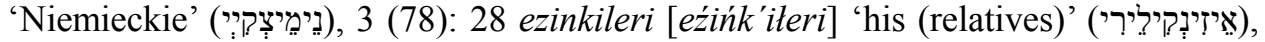

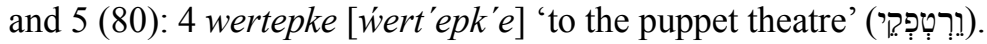

The unexpected use of the letter $k a \bar{p}$ in initial position in certain front words, e.g. the twelve occurrences in words derived from the stem kle- - which, applying Németh's rule, had to be transcribed as $k$ 'te- 'to want, wish' - might be due to the reflection of the original front $k^{\prime}$ ' in this position: tile- 'to want, wish' $>k^{\prime}$ 'ile- $>$ kle-. Most of the unusual appearances of the letter $k a \bar{p}$ in back words can be explained by the maintenance of the original form of writing, e.g. in the original Hebrew word kawod 'sir, sire' and its derivation kanuz 'sir, sire' (< kawnuz < kawodunuz) $<$ Hebrew

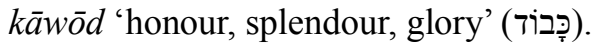

It seems that the orthography does not reflect the theories and assumptions on the representations of the $k$ sounds and that there are still many questions left open about the use of the letters $k a \bar{p}$ and $q \bar{o} p$. Involving new manuscripts in the research might bring us new results.

\section{Conclusion}

As the examples have demonstrated, new editions of texts in different Karaim varieties provide a good basis for a description of Karaim orthography. Based on the writing of the $e$ sounds and the use of different Hebrew letters for realising the $k$ sounds, we can see that it is not possible to describe a unified orthography applicable to all Karaim varieties. On the contrary, a different writing system is used for each Karaim variety. An analysis of the Karaim manuscripts, as we have seen, makes it possible to describe dialectal tendencies. So far, the Crimean Karaim orthography, which avoids the use of several letter combinations and complicated rules, seems to be the simplest one, whereas the most complicated rules and most letter combinations are employed in the Halich Karaim and Lutsk Karaim varieties.

\section{Abbreviations}

\section{Sources}

F103 14-15 a morning prayer written in Halich Karaim, published by Olach (forthcoming)

HKB Halich Karaim Bible, the Halich Karaim translation of biblical texts published by Olach (2013)

KUK Ki uspu kinde, a prayer for the Day of Atonement written in Halich Karaim, published by Jankowski (2011)

Nr. II a poem written in Halich Karaim, published by Grzegorzewski (1903)

Nr. III a poem written in Halich Karaim, published by Grzegorzewski (1903)

Nr. IV a poem written in Halich Karaim, published by Grzegorzewski (1903)

PR2 an evening prayer written in Halich Karaim, published by Olach (2014) 
S

T1 a poem written in Halich Karaim, published by Grzegorzewski (1917)

$\mathrm{T} 2$

Sandyr, a prayer for the Day of Atonement written in Halich Karaim, published by Jankowski (2011)

a poem written in Halich Karaim, published by Grzegorzewski (1917)

\section{Glosses of Karaim examples}

$\begin{array}{ll}\text { ACC } & \text { Accusative } \\ \text { IMP } & \text { Imperative } \\ \text { PL } & \text { Plural }\end{array}$

\section{References}

Csató, Éva Á. (2011): A Typological Coincidence: Word Order Properties in Trakai Karaim Biblical Translations. In: Rona, Bengisu - Erguvanl1-Taylan, Eser (eds): Puzzles of Language. Essays in honour of Karl Zimmer. Wiesbaden (Turcologica), pp. 1-18.

Csató, Éva Á. (2012): Lithuanian Karaim. Journal of Endangered Languages No. 1, pp. 33-45.

Csató, Éva Ágnes - Nathan, David (2007): Multiliteracy, Past and Present, in the Karaim Communities. In: Austin, Peter K. (ed.): Language Documentation and Description 4. London, pp. $207-230$.

Dubiński, Aleksander (1978): Phonetische Merkmale des Łuck-Halicz Dialektes der karaimischen Sprache. $R O$ Vol. 39, No. 2, pp. 33-44.

Firkovičius, Mykolas (1996): Mień karajče ürianiam. Vilnius.

Firkovičius, Mykolas (2000): Šelomonun mašallary. Ankara (TDKY 771).

Grzegorzewski, Jan (1903): Ein türk-tatarischer Dialekt in Galizien: Vokalharmonie in den entlehnten Wörtern der karaitischen Sprache in Halicz. Sitzungsberichte der Kaiserlichen Akademie der Wissenschaften in Wien, Philosophisch-historische Klasse Vol. 146, pp. 1-80.

Grzegorzewski, Jan (1917): Caraimica: Jẹzyk Lach-Karaitów: Narzecze południowe (tucko-halickie). Kraków.

Jankowski, Henryk (1997): A Bible Translation into the Northern Crimean Dialect of Karaim. SO Vol. 82, pp. 1-84.

Jankowski, Henryk (2011): Two Prayers for the Day of Atonement in Translation into the LuckHalicz dialect of Karaim. In: Shapira, Dan. D. Y. - Lasker, Daniel J. - Akhiezer, Golda-Kizilov, Mikhail (eds): Eastern European Karaites in the Last Generations. Jerusalem, pp. $156-170$.

Kowalski, Tadeusz (1929): Karaimische Texte im Dialekt von Troki. Kraków.

Lambdin, Thomas O. (1971): Introduction to Biblical Hebrew. New York.

Munkácsi, Bernát (1909): Karäisch-tatarische Hymnen aus Polen. KSz Vol. 10, pp. 185-210.

Musaev, Kenesbaj M. (1964): Grammatika karaimskogo jazyka. Fonetika i morfologija. Moskva.

Németh, Michał (2011): Unknown Lutsk Karaim Letters in Hebrew Script (19th-20th Centuries). A Critical Edition. Kraków (Studia Turcologica Cracoviensia 12).

Nemoy, Leon (1978): Karaites. In: Donzel, Emeri van-Lewis, Bernard-Pellat, Charles (eds): The Encyclopaedia of Islam IV. Leiden-Boston, pp. 603-608.

Olach, Zsuzsanna (2013): A Halich Karaim Translation of Hebrew Biblical Texts. Wiesbaden (Turcologica 98). 
Olach, Zsuzsanna (2014): A Comparative Study of Two Evening Prayers Written in Karaim. In: Demir, Nurettin-Karakoç, Birsel-Menz, Astrid (eds): Turcology and Linguistics. Éva Ágnes Csató Festschrift. Ankara, pp. 313-326.

Olach, Zsuzsanna (forthcoming): A South-western Karaim Morning Prayer. Tehlikedeki Diller Dergisi. Türk dilleri 2014/4.

Pritsak, Omeljan (1959): Das Karaimische. In: Deny, Jean - Grønbech, Kaare-Scheel, HelmuthTogan, Zeki Velidi (eds): Philologiae Turcicae Fundamenta 1. Wiesbaden, pp. 318-340.

Róna-Tas, András (1998): Turkic Writing Systems. In: Johanson, Lars-Csató, Éva Á. (eds): The Turkic Languages. London-New York, pp. 126-137.

Shapira, Dan (2013): The Karaim Translation of the Book of Nehemia Copied in the 17th Century's Crimea and Printed in 1840/1841 at Gözleve, on the Copyist of the Manuscript, and Some Related Issues. Karaite Archives No. 1, pp. 133-198.

Sulimowicz, Józef (1972): Materiał leksykalny krymskokaraimskiego zabytku językowego (druk z 1734 r.). $R O$ Vol. 35 , pp. 37-76.

Zajączkowski, Ananiasz (1931): Krótki wykład gramatyki języka zachodnio-karaimskiego (narzecze tucko-halickie). Łuck.

Zajączkowski, Ananiasz (1932): Przekłady Trenów Jeremjasza w narzeczu trocko-karaimskiem. $R O$ Vol. 8, pp. 181-192.

Zajączkowski, Ananiasz (1934): Przekłady Trenów Jeremjasza w narzeczu trocko-karaimskiem (tekst i słowniczek). $R O$ Vol. 10, pp. 158-178.

Zajączkowski, Ananiasz (1961): Karaims in Poland. History. Language. Folklore. Science. Warszawa. 